\title{
RESPON PERTUMBUHAN DAN HASIL TANAMAN KACANG KEDELAI TERHADAP DOSIS PUPUK FOSFOR DAN VARIETAS YANG BERBEDA
}

\author{
Aditya Murtilaksono ${ }^{1}$, Mardhiana $^{2}$, Made Emilius Adhi $^{3}$ \\ 1,2,3 Jurusan Agroteknologi Fakultas Pertanian Universitas Borneo Tarakan \\ Jalan Amal Lama Nomor 1 Kelurahan Pantai Amal, Kota Tarakan, 77123 \\ Email: aditwalker02@gmail.com
}

Receive: 22 September 2018

Accepted: 2 Oktober 2018

\begin{abstract}
Glycine max is a plant that can be used as a variety of food ingredients, such as tofu, tempeh, soy sauce. Glycine max production in North Kalimantan in 2017 has decreased production. One effort to increase Glycine max production is to use phosphorus fertilizer. Phosphorus fertilizer has the function of stimulating root growth especially at the beginning of growth, accelerating flowering, ripening of seeds and fruit. Therefore it is necessary to fertilize to increase Glycine max production. The purpose of this study was to determine the response of growth and yield of Glycine max plants to the dose of phosphorus fertilizer ( $p$ ) and different varieties to determine the effect of the interaction between the dose of fertilizer with Glycine max varieties.This study used a factorial randomized block design with 8 treatments, 4 replications to produce 32 treatment units. The first factor is the dose of phosphorus fertilizer consisting of without using P fertilizer (P0), P fertilizer application $0.138 \mathrm{~g}$ per plant (P1), $\mathrm{P}$ fertilizer application $0.276 \mathrm{~g}$ per plant (P2), and P fertilizer application $0.552 \mathrm{~g}$ per plant (P3) . The second factor is Glycine max varieties consisting of Devon 1 varieties (V1) and Dena 1 varieties (V2). Analysis of data using variance with 95\% confidence level and if significantly different, continued with DMRT test. The results obtained are that the dose of phosphorus fertilizer cannot affect the growth and yield of Glycine max plants in Dena 1 and Devon varieties 1 . The use of Dena 1 varieties has a significant effect on the growth and yield of Glycine max plants in the treatment of plant height $3 \mathrm{mst}(34.46 \mathrm{~cm}), 4 \mathrm{mst}$ $(46.35 \mathrm{~cm}), 5 \mathrm{mst}(96.76 \mathrm{~cm})$, main stem diameter $2 \mathrm{mst}(0.33 \mathrm{~cm})$ and plant seed weight $(6.89$ grams $)$ and seed weight per hectare (1.1 tons / ha). There was no interaction with the dose of phosphorus fertilizer and the use of varieties on the growth and yield of Glycine max plants in Dena 1 and Devon 1 varieties.
\end{abstract}

Key words: Fertilizer, Phosphorus, Glycine max, North Borneo

\begin{abstract}
ABSTRAK
Kedelai merupakan tanaman yang dapat dijadikan berbagai macam bahan makanan, contohnya seperti tahu, tempe, kecap. Produksi kedelai di Kalimantan Utara tahun 2017 mengalami penurunan produksi. Salah satu upaya untuk meningkatkan produksi kedelai adalah menggunakan pupuk fosfor. Pupuk fosfor memiliki fungsi Merangsang pertumbuhan akar terutama pada awal-awal pertumbuhan, mempercepat pembungaan, pemasakan biji dan buah.oleh sebab itu perlu dilakukan pemupukan untuk meningkatkan produksi kedelai. Tujuan penelitian ini adalah Mengetahui Respon pertumbuhan dan hasil tanaman kacang kedelai terhadap dosis pupuk fosfor (p) dan varietas yang berbeda mengetahui pengaruh interaksi antara dosis pupuk dengan varietas kacang kedelai. Penelitian ini mengunakan Rancangan Acak Kelompok Faktorial dengan 8 perlakuan, 4 ulangan sehingga menghasilkan 32 unit perlakuan. Faktor pertama yaitu dosis pupuk fosfor yang terdiri dari tanpa menggunakan pupuk $\mathrm{P}(\mathrm{P} 0)$, pemberian pupuk $\mathrm{P} 0,138$ g per tanaman (P1), pemberian pupuk $\mathrm{P} 0,276 \mathrm{~g}$ per tanaman (P2), dan pemberian pupuk $\mathrm{P} 0,552 \mathrm{~g}$ per tanaman (P3). Faktor kedua yaitu varietas tanaman kedelai yang terdiri dari varietas Devon 1 (V1) dan varietas Dena 1 (V2). Analisis data menggunakan sidik ragam dengan tingkat kepercayaan $95 \%$ dan apabila berbeda nyata dilanjut dengan uji lanjut DMRT. Hasil penelitian yang diperoleh adalah Pemberian dosis pupuk fosfor tidak dapat mempengaruhi pertumbuhan dan hasil tanaman kedelai varietas Dena 1 dan Devon 1. Penggunaan varietas Dena 1 berpengaruh nyata terhadap pertumbuhan dan hasil tanaman kedelai pada perlakukan tinggi tanaman $3 \mathrm{mst}(34,46 \mathrm{~cm}), 4 \mathrm{mst}$ $(46,35 \mathrm{~cm}), 5 \mathrm{mst}(96,76 \mathrm{~cm})$, diameter batang utama $2 \mathrm{mst}(0,33 \mathrm{~cm})$ dan berat biji pertanaman $(6,89$ gram$)$ dan berat biji perhektar $(1,1$ ton/ha). Tidak terjadi interaksi pada pemberian dosis pupuk fosfor dan penggunaan varietas terhadap pertumbuhan dan hasil tanaman kedelai varietas Dena 1 dan Devon 1.
\end{abstract}

Kata Kunci: Pupuk, Fosfor, Kedelai (Glycine max), Kalimantan Utara

\section{PENDAHULUAN}

Tanaman Kedelai (Glycine max) merupakan salah satu jenis tanaman pangan penting di Indonesia. Indonesia memiliki 80 varietas unggul, varietas Devon 1 dan Dena 1 merupakan varietas unggulan berasal dari balai Penelitian Tanaman Aneka Kacang dan Umbi (BALITKABI) Malang, Jawa Timur.tanaman kedelai tumbuh baik pada ketinggian $50-150 \mathrm{~m}$ di atas permukaan laut, $\mathrm{pH} 5,5-6$, suhu $25-27^{\circ} \mathrm{c}$, penyinaran penuh minimal 10 jam perhari, dan kelembapan ratarata 65\% (Sumarno, Hartono 1993) Ketersediaan air selama pertumbuhan sangat menentukan daya hasil kedelai. Jika terjadi kekeringan selama pembungaan dan pengisian polong, hasil kedelai akan berkurang (Jackson 2000). Melihat syarat tumbuh tanaman kedelai, maka tanaman kedelai tumbuh di semua jenis 
tanah termasuk tanah yang berada di Kalimantan Utara.

Kalimantan utara termasuk tanah ultisol dengan tingkat kesuburan tanah yang rendah. Menurut Purnomo et al (2011) menyatakan tanah di Hutan Penelitian memiliki pH tanah 3,95 (sangat masam), kandungan $\mathrm{N}$ tanah $0,01 \%$ (sangat rendah), kandungan $\mathrm{P}$ tersedia 0,37 ppm (sangat rendah); kandungan $\mathrm{K}$ tersedia $0,006 \mathrm{~m} / 100 \mathrm{~g}$ (sangat rendah), sehingga secara keseluruhan, tanah ini memiliki status kesuburan sangat rendah.

Upaya peningkatan produksi tanaman dengan tingkat kesuburan tanah rendah melalui Intensifikasi. Salah satu cara intensifikasi lahan yang dilakukan adalah dengan pengunaan pupuk. Pupuk terbagi menjadi anorganik dan organik. Pupuk anorganik merupakan pupuk yang mengandung bahan kimia seperti N, P, K dan pupuk organik adalah pupuk yang berasal dari bahan organik seperti limbah sayuran, daun kering, dan lainnya.

Fosfor merupakah salah satu jenis pupuk anorganik berguna untuk merangsang pertumbuhan akar, khususnya akar benih dan tanaman muda. Selain itu $P$ juga berfungsi sebagai bahan baku untuk pembentukan sejumlah protein serta mempercepat pembungaan, pemasakan biji dan buah. Gejala-gejala kekurangan $\mathrm{P}$ adalah pertumbuhan terhambat (kerdil) karena pembelahan sel terganggu, daun-daun menjadi ungu atau coklat mulai dari ujung daun, dan terlihat jelas pada tanaman yang masih muda (Hardjowigeno 1987). Berdasarkan hal di atas maka akan dilakukan penelitian pemberian pupuk fosfor terhadap pertumbuhan dan hasil tanaman kedelai yang berbeda varietas. Apakah pemberian pupuk fosfor memberikan pengaruh terhadap pertumbuhan dan hasil tanaman kedelai yang berbeda varietas dan berapakah takaran pupuk fosfor yang terbaik terhadap pertumbuhan dan hasil tanaman kedelai yang berbeda varietas

\section{BAHAN DAN METODE}

Penelitian ini dilaksanakan pada tahun 2017 di kebun penelitian Fakultas Pertanian Universitas Borneo Tarakan. Alat yang digunakan dalam penelitian yaitu: cangkul, parang, meteran, skop, ember, tali rapia, kamera, timbangan analitik, jangka sorong, gelas ukur dan oven. Bahan yang digunakan dalam penelitian yaitu benih kedelai Varietas Devon 1, Kedelai Varietas Dena 1, air, pupuk kotoran ayam dan pupuk Fosfor.

Rancangan penelitian ini disusun dengan menggunakan Rancangan Acak Kelompok (RAK) faktorial. Kombinasi dengan 8 perlakuan diulang 4 kali. Secara lengkap tertera pada Tabel 1.

Tabel 1. Kombinasi Varietas Kedelai dan Dosis Pupuk Fosfor

\begin{tabular}{llll}
\hline & Varietas & Devon 1 & Dena 1 \\
\cline { 3 - 4 } Pupuk (p) & & V1 & V2 \\
\hline
\end{tabular}

\begin{tabular}{clll}
\hline $0 \mathrm{~g}$ & $\mathrm{P} 0$ & $\mathrm{P} 0 \mathrm{~V} 1$ & $\mathrm{P} 0 \mathrm{~V} 2$ \\
$0.138 \mathrm{~g}$ & $\mathrm{P} 1$ & P1V1 & P1V2 \\
$0.276 \mathrm{~g}$ & $\mathrm{P} 2$ & P2V1 & P2V2 \\
$0.552 \mathrm{~g}$ & $\mathrm{P} 3$ & P3V1 & P3V2 \\
\hline
\end{tabular}

\begin{tabular}{ll}
\hline Keterangan : & V1 $=$ Devon 1 \\
$\mathrm{P} 0=$ Kontrol & V2 $=$ Dena 1
\end{tabular}

$\mathrm{P} 2=0,276 \mathrm{~g}$ per tanaman

P3 $=0,552$ g per tanaman

Setiap satuan percobaan terdiri dari 16 tanaman. Jarak tanam yang digunakan adalah $25 \times 25$ $\mathrm{cm}$. Jumlah total tanaman kedelai varietas Dena 1 sebanyak 768 tanaman dan varietas Devon 1 sebanyak 768 tanaman.

\section{Pelaksanaan Penelitian}

\section{Pembukaan Lahan}

Sebelum penelitian dimulai akan disiapkan tempat penelitian dengan cara membersihkan lahan dari gulma supaya mempermudah saat menanam kedelai.

\section{Pengolahan Lahan}

Pengolahan tanah pada tanaman kedelai dilakukan dengan cara mencangkul tanah. Pengolahan tanah ini dilakukan satu minggu sebelum tanam. Selanjutnya dibuat bedengan dengan ukuran 1 x 1 meter dengan ketinggian bedengan yaitu $40 \mathrm{~cm}$.

\section{Persiapan Benih}

Benih kedelai yang sudah siap ditanam harus memiliki vigor yang baik. benih kedelai yang baik yaitu yang memiliki daya kecambah lebih dari $80 \%$

\section{Penanaman}

Penamanan dilakukan dengan cara ditugal dengan ukuran bedengan yaitu $1 \times 1$ meter. Penanaman dengan jarak tanam $25 \times 25 \mathrm{~cm}$. Setiap lubang diisi 3 benih pada lubang tugalan dan tutup dengan tanah dengan kedalaman tanam yaitu $5 \mathrm{~cm}$, setelah tanaman berusia 2 minggu akan dilakukan penjarangan dan hanya terdapat 1 tanaman per lubang tanaman.

\section{Pemupukan}

Pemupukan dilakukan dengan dua metode yaitu pemupukan dasar menggunakan pupuk kotoran ayam dan pemberian pupuk perlakuan yaitu pupuk Fosfor.Pemupukan dasar dilakukan satu minggu sebelum tanam, dengan dosis 5 ton/ha atau $31.25 \mathrm{~g}$ pertanaman. Pemupukan perlakuan dilakukan dua kali yaitu pemupukan pertama diberikan pada usia tanaman kedelai 7 HST sebanyak $1 / 2$ dosis perlakuan untuk setiap lubang. Pemberian pemupukan kedua diberikan pada usia tanaman kedelai 30 HST sebanyak $1 / 2$ dosis perlakuan untuk setiap lubang.

\section{Pemeliharaan}

Penyiraman dilakukan apabila tidak terjadi hujan dan dilakukan pagi dan sore hari dengan melihat kelembapan tanah di atas $80 \%$ menggunakan soiltester dan memberikan air dengan takaran yang sama. Penyiangan dilakukan dengan cara mencabut gulma yang dapat menghambat pertumbuhan tanaman kedelai dan dilakukan dua minggu sekali. Pembumbunan 
dilakukan dengan cara menggaruk tanah disekitar tanaman kedelai. Pembumbunan bertujuan untuk mengemburkan tanah selain itu dapat memperkokoh tanaman agar tidak rusak.

\section{Panen}

Tanaman kedelai varietas Devon 1 bisa dipanen pada usia tanaman 78 HST dan varietas dena 1 bisa dipanen pada usia tanaman mencapai 78 HST. Namun dalam penelitian ini kedua varietas dipanen pada usia tanaman 78 HST. Ciri-ciri tanaman kedelai yang siap dipanen yaitu dapat dilihat dari daun dan polong mulai menguning. Panen dilakukan dengan cara memotong bagian pangkal batang di atas permukaan tanah menggunakan parang. Berangkasan dijemur sampai kering, setelah kering dilakukan pemisahan antara biji dan berangkasannya. Kemudian biji dibersihkan dari berangkasannya, selanjutnya biji dijemur dengan sinar matahari sampai kering. selanjutnya biji disimpan.

\section{Parameter Pengamatan \\ Tinggi Tanaman}

Pengamatan tinggi tanaman kedelai dimulai dari pangkal batang hingga daun tertinggi tanaman kedelai. Pengamatan dilakukan mulai pada umur 2, 3, 4 dan 5 MST. Alat yang digunakan yaitu meteran untuk mengukur tinggi tanaman kedelai.

\section{Jumlah Daun}

Jumlah daun dihitung mulai pada umur 2, 3, 4 dan 5 MST. Pengamatan dilakukan secara manual mulai dari daun tertua sampai daun termuda.

\section{Diameter Batang Utama}

Diameter batang utama dihitung mulai 2, 3, 4 dan 5 MST. Alat yang digunakan yaitu jangka sorong untuk mengukur diameter batang utama tanaman kedelai, Batang yang diukur adalah $5 \mathrm{~cm}$ di atas permukaan tanah

\section{Jumlah Polong Per Tanaman}

Pengamatan jumlah polong per tanaman diamati setelah tanaman kedelai memasuki masa panen, dilakukan dengan menghitung jumlah polong per tanaman yang dihasilkan kedelai tersebut.

\section{Berat Polong Per Tanaman}

Dihitung dengan cara menimbang berat polong per tanaman dengan menggunakan timbangan analitik dan dilakukan pada saat panen.

\section{Jumlah Biji Pertanaman}

Pengamatan dlakukan setelah tanaman kedelai dipanen dengan menghitung jumlah biji di dalam polong tanaman kedelai.

\section{Berat Biji Per Tanaman}

Ditimbang berat biji per tanaman dengan menggunakan timbangan analitik dilakukan pada saat panen

\section{Berat Biji Per Hektar}

Berat biji per hektar merupakan hasil konversi dari perhitungan berat biji per tanaman. Rumus untuk berat biji per hektar sebagai berikut:

Hasil kedelai ( ton)

\section{Analisis data}

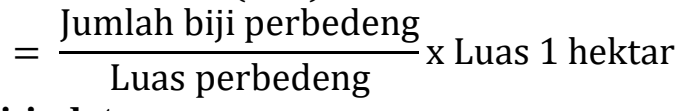

Data yang telah diperoleh akan dianalisis menggunakan Analysis of Variance (ANOVA) dengan taraf 5\% apabila nilai $\mathrm{F}$ hitung menunjukkan pengaruh yang nyata, maka dilanjutkan dengan uji Duncan Multiple Test (DMRT) dengan taraf kepercayaan 95\% untuk mengetahui perbedaan antar perlakuan.

\section{HASIL DAN PEMBAHASAN}

Hasil

Pengamatan tanaman kedelai terdiri dari parameter pertumbuhan dan paramater hasil tanaman. parameter pertumbuhan tanaman kedelai berupa tinggi tanaman, jumlah daun dan diameter batang utama. Parameter hasil tanaman kedelai berupa jumlah polong, berat polong, berat biji dan jumlah biji. Hasil uji F pada parameter tertera pada Tabel 2

Tabel 2. Hasil Anova Parameter Pertumbuhan Tanaman Kedelai

\begin{tabular}{|c|c|c|c|c|c|}
\hline \multirow{2}{*}{ No } & \multirow{2}{*}{ Parameter Pengamatan } & \multicolumn{4}{|c|}{ Nilai F-Hitung Anova } \\
\cline { 3 - 5 } & & Varietas & Pupuk & Interaksi & Koefisien keragaman \\
\hline 1 & Tinggi Tanaman 2 MST & $0,32 \mathrm{tn}$ & $1,06 \mathrm{tn}$ & $0,38 \mathrm{tn}$ & 11,25 \\
\hline 2 & Tinggi Tanaman 3 MST & $14,48 *$ & $1,31 \mathrm{tn}$ & $1,32 \mathrm{tn}$ & 7,88 \\
\hline 3 & Tinggi Tanaman 4 MST & $16,56^{*}$ & $2,12 \mathrm{tn}$ & $1,72 \mathrm{tn}$ & 7,53 \\
\hline 4 & Tinggi Tanaman 5 MST & $4,50 *$ & $0,93 \mathrm{tn}$ & $1,47 \mathrm{tn}$ & 13,01 \\
\hline 5 & Jumlah Daun 2 MST & $0,23 \mathrm{tn}$ & $0,28 \mathrm{tn}$ & $2,81 \mathrm{tn}$ & 18,79 \\
\hline 6 & Jumlah Daun 3 MST & $0,16 \mathrm{tn}$ & $2,89 \mathrm{tn}$ & $2,74 \mathrm{tn}$ & 8,81 \\
\hline 7 & Jumlah Daun 4 MST & $0,05 \mathrm{tn}$ & $1,08 \mathrm{tn}$ & $0,83 \mathrm{tn}$ & 12,14 \\
\hline 8 & Jumlah Daun 5 MST & $0,48 \mathrm{tn}$ & $2,10 \mathrm{tn}$ & $2,31 \mathrm{tn}$ & 3,34 \\
\hline 9 & Diameter Batang Utama 2 MST & $5,53 *$ & $1,88 \mathrm{tn}$ & $2,74 \mathrm{tn}$ & 8,25 \\
\hline 10 & Diameter Batang Utama 3 MST & $1,06 \mathrm{tn}$ & $0,98 \mathrm{tn}$ & $0,95 \mathrm{tn}$ & 131,85 \\
\hline 11 & Diameter Batang Utama 4 MST & $1,45 \mathrm{tn}$ & $1,78 \mathrm{tn}$ & $2,49 \mathrm{tn}$ & 11,42 \\
\hline 12 & Diameter Batang Utama 5 MST & $0,51 \mathrm{tn}$ & $3,00 \mathrm{tn}$ & $1,83 \mathrm{tn}$ & \\
\hline & F- Tabel & 4,16 & 3,07 & 3,07 & 4,53 \\
\hline
\end{tabular}

Keterangan $*=$ berpengaruh nyata, $\mathrm{tn}=$ berpengaruh tidak nyata

Berdasarkan Tabel 2, hasil nilai F-hitung Anova pada paramater pertumbuhan tanaman kedelai menunjukkan bahwa faktor interaksi varietas dan pupuk $\mathrm{P}$ berpengaruh tidak nyata terhadap semua parameter pertumbuhan. Faktor tunggal varietas berpengaruh nyata terhadap parameter tinggi tanaman 
3,4, dan 5 MST, serta diameter batang $2 \mathrm{mst}$, Sedangkan faktor tunggal pupuk $\mathrm{P}$ berpengaruh tidak nyata terhadap semua parameter pertumbuhan.

Berdasarkan hasil Uji F paramater pertumbuhan kedelai apabila terdapat data berpengaruh nyata maka dilanjut uji lanjut DMRT. Data hasil uji lanjut DMRT pengamatan tinggi tanaman kedelai Umur 3, 4, dan 5 mst pada Tabel 3 .

Tabel 3. Rata-rata Tinggi Tanaman (cm) Kedelai 3, 4 dan 5 MST

\begin{tabular}{llll}
\hline Varietas & 3 MST & 4 MST & 5 MST \\
\hline Devon 1 & $30,99 \mathrm{a}$ & $41,59 \mathrm{a}$ & $89,57 \mathrm{a}$ \\
Dena 1 & $34,46 \mathrm{~b}$ & $46,35 \mathrm{~b}$ & $98,76 \mathrm{~b}$ \\
\hline
\end{tabular}

Ket: Angka yang diikuti oleh huruf sama dalam kolom, tidak berbeda nyata berdasarkan Uji lanjut DMRT pada taraf 5\%

Berdasarkan uji lanjut DMRT diketahui bahwa faktor tunggal varietas yaitu Devon 1 berbeda nyata dengan varietas Dena 1 (Tabel 3). Tinggi tanaman pada varietas Dena 1 konsisten lebih tinggi dari pada varietas Devon 1 pada umur 3,4,dan 5 mst.

Tabel 5. Hasil F-Hitung Parameter Hasil Tanaman Kedelai

Tabel 5. Hasil F-Hitung Parameter Hasil Tanaman Kedelai
\begin{tabular}{|c|c|c|c|c|c|}
\hline \multirow{2}{*}{ No } & \multirow{2}{*}{ Parameter Pengamatan } & \multicolumn{4}{|c|}{ Hasil Anova } \\
\cline { 3 - 6 } & & Varietas & Pupuk & Interaksi & Koefisien keragaman \\
\hline 1 & Jumlah Polong & $0,42 \mathrm{tn}$ & $1,30 \mathrm{tn}$ & $1,08 \mathrm{tn}$ & 25,68 \\
\hline 2 & Berat Polong & $0,94 \mathrm{tn}$ & $0,17 \mathrm{tn}$ & $2,07 \mathrm{tn}$ & 28,88 \\
\hline 3 & Jumlah Biji & $1,54 \mathrm{tn}$ & $0,14 \mathrm{tn}$ & $0,39 \mathrm{tn}$ & 35,91 \\
\hline 4 & Berat Biji Pertanaman & $9,19^{*}$ & $1,12 \mathrm{tn}$ & $1,90 \mathrm{tn}$ & 51,39 \\
\hline 5 & Berat Biji Perhektar & $9,20^{*}$ & $1,12 \mathrm{tn}$ & $1,90 \mathrm{tn}$ & 51,38 \\
\hline \multicolumn{2}{|c|}{ F-Tabel } & 4,16 & 3,07 & 3,07 & \\
\end{tabular}

Keterangan $*=$ berpengaruh nyata, $\mathrm{tn}=$ berpengaruh tidak nyata
Berdasarkan Tabel 5. menunjukkan bahwa perlakuan interaksi pupuk dan varietas, berpengaruh tidak nyata terhadap semua faktor parameter hasil tanaman kedelai. Faktor tunggal dari perlakuan pupuk fosfor berpengaruh tidak nyata semua terhadap semua parameter hasil tanaman kedelai. Faktor tunggal dari varietas berpengaruh tidak nyata terhadap jumlah polong, berat polong dan jumlah biji, tapi berpengaruh nyata pada berat biji pertanaman dan berat biji perhektar.

Berdasarkan hasil Uji $\mathrm{F}$ paramater hasil kedelai apabila terdapat data berpengaruh nyata maka dilanjut uji lanjut DMRT. Data hasil parameter berat biji pertanaman tanaman kedelai dilakukan pengamatan pada saat tanaman kedelai panen yaitu pada tanaman kedelai berumur 78 HST hasil uji lanjut DMRT terdapat pada Tabel 6.

Tabel 6. Rata-rata Berat biji Pertanaman Kedelai

\begin{tabular}{ll}
\hline Varietas & Berat biji (gram/tanaman) \\
\hline Dena 1 & $6,89 \mathrm{~b}$ \\
Devon 1 & $3,91 \mathrm{a}$ \\
\hline
\end{tabular}

Ket: Angka yang diikuti oleh huruf sama dalam kolom, tidak berpengaruh nyata berdasarkan Uji lanjut DMRT pada taraf 5\%

Berdasarkan uji lanjut Duncan diketahui bahwa faktor tunggal varietas yaitu Devon 1 berbeda
Data hasil uji lanjut DMRT pengamatan diameter batang utama tanaman kedelai pada umur

Tabel 4. Rata-rata Diamater Batang Utama (cm) Kedelai 2 MST

\begin{tabular}{ll}
\hline Varietas & $2 \mathrm{MST}$ \\
\hline Dena 1 & $0,33 \mathrm{~b}$ \\
Devon 1 & $0,31 \mathrm{a}$ \\
\hline
\end{tabular}

Ket: Angka yang diikuti oleh huruf sama dalam kolom, tidak berpengaruh nyata berdasarkan Uji lanjut DMRT pada taraf 5\%

Berdasarkan uji lanjut DMRT diketahui bahwa faktor tunggal varietas yaitu Devon 1 berbeda nyata dengan varietas Dena 1 (Tabel 4). Diameter Batang Utama pada varietas Dena 1 memiliki diameter batang utama lebih tinggi yaitu 0,33 . dibandingkan varietas Devon 1. yaitu 0,31.

Pengamatan paramater pertumbuhan Hasil tanaman kedelai terdiri dari jumlah polong, berat polong, jumlah biji, berat biji pertanaman dan berat biji perhektar. Hasil Anova parameter pertumbuhan tanaman kedelai tertera pada Tabel 5. tanaman 2 MST terdapat pada Tabel 4.

nyata dengan varietas Dena 1 (Tabel 6). Berat biji varietas Dena 1 lebih tinggi dari varietas Devon 1.

Data hasil parameter berat biji perhaktar merupakan hasil konversi perhitungan dari parameter biji pertanaman. Hasil uji lanjut DMRT terdapat pada Tabel .

Tabel 7. Rata-rata Berat Biji Perhaktar Tanaman Kedelai

\begin{tabular}{ll}
\hline Varietas & Berat biji (Ton/Ha) \\
\hline Dena 1 & $881,716 \mathrm{~b}$ \\
Devon 1 & $500,820 \mathrm{a}$ \\
\hline
\end{tabular}

Ket: Angka yang diikuti oleh huruf sama dalam kolom, tidak berpengaruh nyata berdasarkan Uji lanjut DMRT pada taraf 5\%

Berdasarkan uji lanjut Duncan diketahui bahwa faktor tunggal varietas yaitu Devon 1 berbeda nyata dengan varietas Dena 1 (Tabel 7). Berat biji perhektar pada varietas Dena 1 lebih tinggi dari pada varietas Devon 1.

\section{Pembahasan}

Penelitian yang berjudul pengaruh dosis pupuk fosfor terhadap pertumbuhan dan hasil tanaman Kedelai varietas Dena 1 dan Devon 1 terdapat dua parameter yaitu parameter utama dan parameter 
pendukung. Parameter utama yang meliputi parameter pertumbuhan dan hasil tanaman kedelai. Parameter pertumbuhan yang berupa tinggi tanaman, jumlah daun, dan diameter batang utama tanaman kedelai tidak terjadi interaksi antara varietas dengan dosis pupuk dan tidak berpengaruh nyata terhadap penggunaan dosis pupuk fosfor.

Proses penyerapan fosfor untuk kedua varietas

Dena 1 dan Devon 1 sangat lama. Menurut Bunemann (2015) menyatakan bahwa penyerapan unsur hara fosfor pada tanaman di tanah masam sangat lambat. Tanaman menyerap fosfor dengan bantuan mikrobakteria. mikrobakteria akan mengeluarkan enzim fosfatase untuk menyederhanakan unsur hara fosfor sehingga tanaman dapat menyerap fosfor. Mikrobakteria di tanah masam sangat terbatas jumlahnya, karena mikrobakteria tertentu tidak dapat hidup di tanah sehingga penyerapan hara fosfor tidak maksimal.

Penelitian ini juga mengamati parameter hasil tanaman kedelai. Parameter Parameter hasil tanaman kedelai tidak berpengaruh nyata karena kurangnya asupan nutris $\mathrm{N}$ dan $\mathrm{K}$ sehingga tanaman kesulitan untuk bertumbuh dan berkembang. Pemakaian pupuk majemuk NPK akan memberi suplai $\mathrm{N}$ yang cukup besar ke dalam tanah, sehingga dengan pemberian pupuk NPK yang mengandung nitrogen tersebut akan membantu pertumbuhan tanaman. Pupuk NPK merupakan pupuk majemuk yang terdiri dari pupuk tunggal N, P dan K. Hakim et al (1986) menyatakan bahwa penggunaan pupuk NPK mempunyai faktor positif dan negatif. Faktor positif dari pupuk NPK adalah sebagai berikut: pupuk buatan memiliki konsentrasi hara yang tinggi sehingga memudahkan dalam pemakaian.

Hasil uji sidik ragam menunjukkan bahwa pada parameter tinggi tanaman 3, 4 dan 5 mst dan juga parameter diameter batang utama pada 2 mst serta berat biji kacang kedelai menunjukkan hasil yang berbeda nyata terhadap varietas kedelai Dena 1 dan Devon 1, hal ini diakibatkan karena varietas Dena 1 dan Devon 1 memiliki klasifikasi dan ciri khas yang berbeda-beda, baik pada proses penyerapan unsur hara maupun produksi kacang kedelai yang dihasilkan varietas Dena 1 merupakan varietas yang memiliki umur panen dan masa berbunga yang paling cepat dari pada Devon 1 (Balitbang pertanian 2015), Varietas Dena 1 lebih cepat dalam penyerapan unsur hara diantaranya unsur hara $\mathrm{P}$ sehingga varietas ini memiliki tinggi tanaman, diameter batang dan juga berat biji yang lebih tinggi dibandingkan varietas Devon 1.

Unsur hara $\mathrm{P}$ pada fase vegetatif tanaman berfungsi merangsang pertumbuhan akar, khususnya akar benih dan tanaman muda (Hardjowigeno 1987). Pertumbuhan akar yang lebih banyak dan panjang sangat berkaitan dengan proses penyerapan hara khususnya unsur hara P. Selain itu menurut Tisdale et al (1985) unsur hara P berfungsi sebagai pembentukan batang.

Hasil kedelai ( ton)

$=\frac{\text { Jumlah biji perbedeng }}{\text { Luas perbedeng }} \times$ Luas 1 hektar

Pada parameter berat biji perhektar diperoleh hasil pada tanaman kacang kedelai varietas Devon 1 hasil tertinggi sebesar 0,6 ton $(619 \mathrm{~kg})$ pada tanaman kacang kedelai varietas Dena 1 hasil tertinggi sebesar 1,1 ton. Sedangkan menurut Mansuri (2010) yang ditemukan pada daerah Jawa potensi hasil kacang kedelai Devon 1 sebesar 2,75 ton dan varietas Dena 1 sebesar 2,9 ton. Hal ini disebabkan karena perbedaan iklim dan jenis tanah antara daerah Kalimantan dengan daerah Jawa yang cukup signifikan, pada daerah Jawa pH tanah berada di antara 5-7 karena memiliki banyak gunung berapi, abu vulkanik mengandung mineral yang dibutuhkan oleh tanah dan tanaman dengan komposisi total unsur tertinggi yaitu $\mathrm{Ca}, \mathrm{Na}, \mathrm{K}$ dan $\mathrm{Mg}$ unsur makro lain berupa $\mathrm{P}$ dan $\mathrm{S}$, sedangkan unsur mikro terdiri dari $\mathrm{Fe}, \mathrm{Zn}, \mathrm{Mn}, \mathrm{Cu}$ (Anda, wahdini 2010).

Kandungan dari debu vulkanik tersebut akan membantu untuk meningkatkan $\mathrm{pH}$ tanah, daerah Kalimantan tidak memiliki gunung merapi sehingga tanah tersebut tandus dan tidak subur jenis tanahnya juga terdiri dari tanah liat dan sebagian besar tanah gambut sehingga sangat mudah menyebabkan cekaman kekeringan. Perbedaan iklim juga menyebabkan pertumbuhan hasil produksi pada daerah tertentu pada daerah Jawa iklim di daerah tersebut masih dapat diprediksi antara musim hujan dan kemarau, untuk daerah Tarakan iklimnya berubahubah dan sulit untuk diprediksi, sehingga tanaman tropis yang ditanaman pada daerah tersebut tidak akan sama hasilnya dengan daerah Jawa.

Permasalahan penting dari $\mathrm{P}$ adalah sebagian $P$ di dalam tanah umumnya tidak tersedia untuk tanaman, meskipun jumlah totalnya lebih besar dari pada nitrogen. Hal ini disebabkan ketersediaan P di dalam tanah tergantung kepada sifat dan ciri tanah itu sendiri, serta sistem pengelolaan tanah itu. penambahan $\mathrm{P}$ ke dalam tanah hanya bersumber dari deposit atau pelapukan batuan dan mineral yang mengandung fosfor. Oleh karena itu, kandungan $\mathrm{P}$ di dalam tanah tergantung banyak sedikitnya cadangan mineral fosfor dan tingkat pelapukannya (Damanik et al. 2010).

\section{KESIMPULAN}

Berdasarkan hasil penelitian yang berjudul Respon pertumbuhan dan hasil tanaman kacang kedelai terhadap dosis pupuk fosfor (p) dan varietas yang berbeda Dena 1 dan Devon 1 dapat disimpulkan Pemberian dosis pupuk fosfor tidak dapat mempengaruhi pertumbuhan dan hasil tanaman kedelai varietas Dena 1 dan Devon 1 
Penggunaan varietas Dena 1 berpengaruh nyata terhadap pertumbuhan dan hasil tanaman kedelai pada perlakukan tinggi tanaman 3 MST $(34,46 \mathrm{~cm}), 4$ MST $(46,35 \mathrm{~cm}), 5 \mathrm{mst}(96,76 \mathrm{~cm})$, diameter batang utama $2 \mathrm{mst}(0,33 \mathrm{~cm})$ dan berat biji pertanaman $(6,89$ gram) dan berat biji perhektar (1,1 ton/ha)

Tidak terjadi interaksi pada pemberian dosis pupuk fosfor dan penggunaan varietas terhadap pertumbuhan dan hasil tanaman kedelai varietas Dena 1 dan Devon 1

\section{DAFTAR PUSTAKA}

Anda, M. dan W. Wahdini. 2010. Sifat, Komposisi Mineral, dan kandungan Berbagai Unsur dan Adu Erupsi Merapi. Bogor: Balai Besar penelitian dan Pengembangan Sumber daya Lahan pertanian.

Bünemann, E.K., 2015. Assessment of gross and net mineralization rates of soil organic phosphorus -a review. Soil Biol. Biochem. 89, 82e98. https://doi.org/10.1016/j.soilbio.2015.06.026

Damanik, M. M. B., B. Effendi, Fauzi, Sarifuddin, H. Hanum. 2010. Kesuburan Tanah dan
Pemupukan.Fakultas Pertanian. Universitas Sumatera Utara Press. Medan.

Hakim, N., Nyakpa, M.Y., Lubis, A.M., Nugroho, S.G., Diha, M.A., Hong, G.B.,Bailey, H.H. 1986. Dasar-Dasar Ilmu Tanah. Universitas Lampung. Lampung

Hardjowigeno, S. 1987. Ilmu Tanah. Mediyatama Sarana Perkasa. Jakarta.

Jackson, I. J. 2000. Climate, Water and Agriculture in the tropics. Longman. London

Manshuri, A.G. 2010. Pemupukan N, P, dan K pada kedelai sesuai kebutuhan tanaman dan daya dukung lahan. Penelitian Pertanian Tanaman Pangan 29(3): 171-179.

Purnomo E, Saputra PJ, Wahyudi F, Tambunan RP and Subandrio A (2011) Companion Plant System: a strategy to grow trees on an extreme soil. 2011

Sumarno dan Hartono. 1993. Pedoman Bercocok Tanam Kedelai. Pusat Penelitian dan Pengembangan Tanaman Pangan, Bogor

Tisdale, S.L., W.L. Nelson and J.D.Beaton. 1985. Soil Fertility and Fertilizers 4tn ed. MacMillan Publishing Company. New York 